\title{
Genetic Variation of Apolipoprotein E (ApoE) in Surabaya, Palu and Alor Populations of Indonesia
}

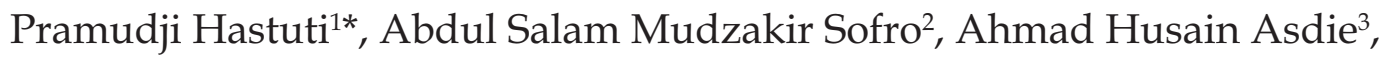 \\ and Ahmad Hamim Sadewa ${ }^{1}$
}

\begin{abstract}
${ }^{1}$ Department of Biochemistry, Faculty of Medicine, Universitas Gadjah Mada, Yogyakarta, Indonesia ${ }^{2}$ Department of Biochemistry, Faculty of Medicine, YARSI University, Jakarta, Indonesia

${ }^{3}$ Department of Internal Medicine, Faculty of Medicine, Universitas Gadjah Mada, Yogyakarta, Indonesia
\end{abstract}

\begin{abstract}
Apolipoprotein E (ApoE) has been considered to play an important role in cardiovascular disorders. Several studies reported that genetic variation in ApoE locus influence plasma lipoprotein level. The objectives of this study was to compare the frequency of ApoE genotypes and alleles in some populations of Indonesia. One hundred and ninety five voluntarily unrelated apparently healthy individuals were recruited from Surabaya, Palu and Alor representing the western, middle and eastern populations of Indonesia, respectively. Blood samples were collected from each subject for DNA extraction. The common allelic variants of ApoE were screened using polymerase chain reaction (PCR) and restriction fragment length polymorphism. Three alleles i.e. $\varepsilon 2, \varepsilon 3$ and $\varepsilon 4$ were identified and five genotypes i.e. $A p o E \varepsilon 2 / \varepsilon 2$, $A p o E \varepsilon 2 / \varepsilon 3, A p o E \varepsilon 3 / \varepsilon 3, A p o E \varepsilon 2 / \varepsilon 4, A p o E \varepsilon 3 /$ $\varepsilon 4$ were found in three populations studied, while $A p o E \varepsilon 4 / \varepsilon 4$ was absent in Surabaya, representing the western populations of Indonesia. The frequency of $\varepsilon 2, \varepsilon 3$ and $\varepsilon 4$ alleles in the western population were $0.208,0.701$ and 0.092 respectively; in the middle population were $0.242,0.618$ and 0.140 respectively and in the eastern population of Indonesia were $0.267,0.466$ and 0.267 respectively. The highest frequency of $\varepsilon 2$ and $\varepsilon 4$ allele was found in the eastern population of Indonesia. The distribution of $\varepsilon 2$ allele were not significantly different among all Indonesian populations, but significantly different were found in $\varepsilon 3$ and $\varepsilon 4$ allele in the eastern population compared to those in the western and middle populations of Indonesian. It can be concluded that the frequency of three ApoE alleles in the western and middle populations of Indonesia was not significantly different however, significantly different was observed in the frequency of $\mathrm{ApoE} \varepsilon 3$ and $\varepsilon 4$ alleles from the eastern compared to those in the western and middle populations of Indonesia.
\end{abstract}

Keywords : Apolipoprotein E; genotypes; allele frequency; populations of Indonesia

\section{Introduction}

Apolipoprotein E (ApoE), a 34-kDa glycoprotein, plays an important role in the transport and metabolism of plasma cholesterol and triglycerides through its ability to interact with cell surface of low density lipoprotein (LDL) receptor and LDL receptor-related protein (LRP). ApoE

\footnotetext{
*Corresponding author:

Pramudji Hastuti

Department of Biochemistry, Universitas Gadjah

Mada, Sekip Utara Yogyakarta, Indonesia,

Tel.: 62-274-6492446,

Email: hpramudji@yahoo.com
}

exists in three isoforms (ApoE2, E3, and E4) that differ in their cysteine/arginine content at two polymorphic sites (Corella et al., 2002). Three common ApoE alleles have been identified: ApoE2, ApoE3, and ApoE4 (Elousa et al., 2004). The encoded 299-residue plasma protein ApoE is a surface component of primarily triglyceride-rich lipoproteins, such as very low-density lipoproteins (VLDLs), chylomicron remnant, and high density lipoproteins (HDLs). ApoE is the main ligand for clearance of VLDLs and chylomicron remnant, and as such affects circulating concentrations of lipoproteins and 
plasma levels of cholesterol and triglycerides (Mahley \& Ji, 1999). Genetic variation in the ApoE locus significantly affects plasma lipoprotein concentrations. The allele of ApoE is associated with increased risk of two major causes of death in low-mortality populations: ischemic heart disease and Alzheimer's disease. The presence of the $\varepsilon 4$ allele is associated with increased LDL cholesterol, whereas the presence of the $\varepsilon 2$ allele is associated with decreased LDL cholesterol and may protect against mortality due to coronary heart disease and Alzheimer's (Douglas, 2002; Jurcovicova et al., 2006, Minihane et al, 2007). Meta-analyses suggest that $A p o E 4$ carrier may have a $40-50 \%$ increased CVD risk, however the associations reported in individual studies are highly heterogeneous and environmental factors influence genotype-phenotype associations (Minihane et al., 2007). Both ApoE2 and ApoE4 are also associated with increases in plasma triglycerides although the ApoE2 allele is associated with a lower CVD risk in women in the Framingham Study (Elousa et al., 2004). The frequencies of these three ApoE alleles are highly variable in different populations (Singh et al., 2006). Globally, $\varepsilon 3$ allele is the most frequently found, constituting $60-90 \%$ of the allelic variation, $\varepsilon 2$ allele constitutes 0-20\% and E4i allele 10-20\% of allelic variation(Elousa et al., 2004; Gerdes et al., 1996).

Indonesia is a country in Southeast Asia and Oceania, comprising 17,508 islands. Across its many islands, Indonesia consists of a variety of distinct ethnic, linguistic, and religious groups. Most Indonesians are descendent from Austronesian-speaking peoples whose languages can be traced to Proto Austronesian, which is likely originated from Taiwan. The other major grouping is Melanesians, inhabiting the eastern part of Indonesia (Dawson \& Gillow, 1994). There are around 300 distinct native ethnicities in Indonesia, and 742 different languages and dialects (Merdekawaty, 2006). The objectives of this work is to study ApoE genotypes and allele polymorphism in Surabaya, Palu and Alor populations, representing the western, middle and eastern populations of Indonesia.

\section{Materials and Methods}

All individuals were recruited as part of a comprehensive study on the "Interaction of biochemical genetic traits and other markers in malaria endemic areas in Indonesia". All subjects were voluntarily unrelated apparently healthy individuals and all of their grandparents were born and belong to a particular ethnic in the study area. Among 195 subjects involved in the study, 82, 68 and 45 individuals were from Surabaya, Palu and Alor representing the western, middle and eastern populations of Indonesia respectively. Written informed consent was obtained from all individuals, and ethical clearance for the project was provided by Human Research and Ethics Committee of the Faculty of Medicine Universitas Gadjah Mada, Yogyakarta. Approximately $10 \mathrm{~mL}$ venous blood was drawn from ante cubital vein of each individuals employing EDTA anticoagulated vacutainer (Terumo). The blood was stored in $4^{\circ} \mathrm{C}$ and brought to the laboratory in Yogyakarta prior to laboratory examination.

\section{DNA analysis}

Genomic DNA was isolated from blood leukocytes using a standard phenolchloroform extraction procedure. Polymerase chain reaction (PCR) amplification was undertaken using forward primer: 5'-TCCAAGGAGCTGCAGGCGGCGA-3' and reverse primer: $5^{\prime}$-GCCCGGCCTG GTACACTGCCA-3' to produce a 218-bp product. The mixture was a mix Promega $12.5 \mathrm{uL}$, forward and reverse primers $1 \mu \mathrm{L}$, water $9.5 \mu \mathrm{L}$, and DNA $1 \mu \mathrm{L}$ was subjected in PCR reaction. PCR conditions used in amplification were $94^{\circ} \mathrm{C}$ for $1 \mathrm{~min}$, followed by 40 cycles of $94^{\circ} \mathrm{C}$ for $30 \mathrm{sec}, 60^{\circ} \mathrm{C}$ for 30 sec, and $70^{\circ} \mathrm{C}$ for $90 \mathrm{sec}$ for extension and a final extension cycle of $72^{\circ} \mathrm{C}$ for $10 \mathrm{~min}$. 
Amplified DNA $8 \mu \mathrm{L}$ was digested with 2.5 $\mathrm{U}$ Afl III and $5 \mathrm{U}$ Hae II for $24 \mathrm{~h}$ at $37^{\circ} \mathrm{C}$. The result was analyzed on $4 \%$ agarose gel and visualized by ethidium bromide staining. Digested product were 145-bp, 168-bp and $195 \mathrm{bp}$ wich were specific for ApoE3, E2 and E4 (Zivelin et al., 1997). The genotype of ApoE in populations was compared employing Chi square analysis, and significant difference was agreed when $p<0,05$.

\section{Results}

Despite abundant reports on the genetic variation of ApoE gene locus, the distribution of ApoE alleles particularly $\varepsilon 2, \varepsilon 3$ and $\varepsilon 4$ are scarcely available in Indonesian populations, if any. In this report variation of ApoE gene locus were found in three Indonesian populations studied (Figure 1 and Figure 2). The frequency of ApoE genotypes and alleles were shown in Table 1 and Figure 2.

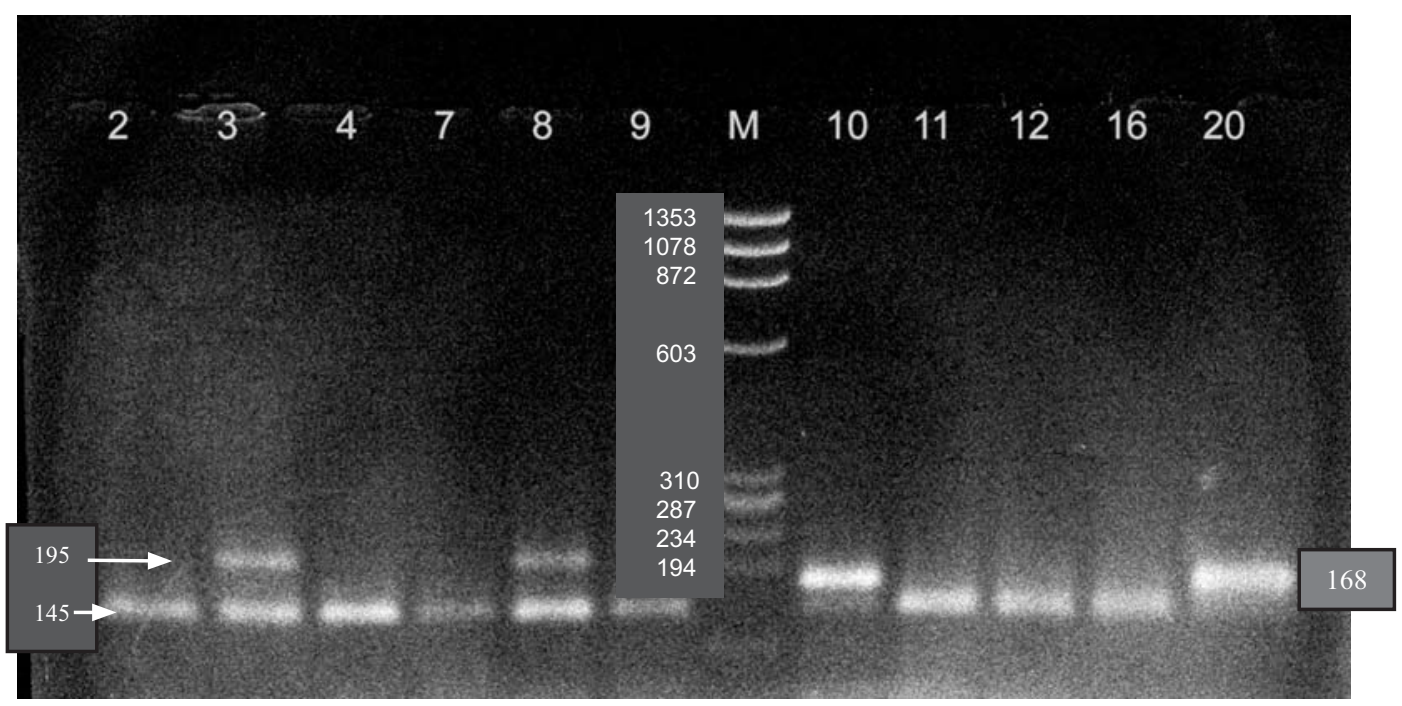

Figure 1 : Apolipoprotein E products after restriction by Afl III \& Hae II enzymes.

Notes: $A p o E \varepsilon 2$ generated bands 168 and 50 bp, ApoE $\varepsilon 3$ generated bands 145, 50 and 23 bp and ApoE $\varepsilon 4$ generated bands 195 and 23 bp. No 2,4,7,9,11,12,16 were ApoE $\varepsilon 3 / \varepsilon 3$ genotype, no 3 and 8 were ApoE $\varepsilon 3 / \varepsilon 4$ genotype, no 10 was ApoE $\varepsilon 2 / \varepsilon 3$, no 20 was ApoE $\varepsilon 2 / \varepsilon 2$ genotype and $\mathrm{M}$ was marker $\varphi x 174$

Table 1. Distribution of apolipoprotein E (ApoE) genotypes and alleles in Surabaya, Palu and Alor representing the western, middle and eastern populations of Indonesia

\begin{tabular}{lcccccc}
\hline $\begin{array}{l}\text { Apolipo- } \\
\text { proteinE } \\
\text { (ApoE) }\end{array}$ & $\begin{array}{c}\text { Surabaya } \\
(\mathrm{n}=82)\end{array}$ & $\begin{array}{c}\text { P Surabaya } \\
\text { Palu }\end{array}$ & $\begin{array}{c}\text { Palu } \\
(\mathrm{n}=68)\end{array}$ & $\begin{array}{c}\text { P Palu- } \\
\text { Alor }\end{array}$ & $\begin{array}{c}\text { Alor } \\
(\mathrm{n}=45)\end{array}$ & $\begin{array}{c}\text { P } \\
\text { Surabaya- } \\
\text { Alor }\end{array}$ \\
\hline Genotype & & & & & & $\mathbf{0 . 0 0 0}$ \\
$\varepsilon 2 / \varepsilon 2$ & $7(8.5 \%)$ & $\mathbf{0 . 0 8 8}$ & $5(7.4 \%)$ & & $7(15.6 \%)$ & - \\
$\varepsilon 2 / \varepsilon 3$ & $15(18.3 \%)$ & & $21(30.9 \%)$ & $7(15.6 \%)$ & \\
$\varepsilon 3 / \varepsilon 3$ & $45(54,9 \%)$ & & $25(36.8 \%)$ & & $8(17.8 \%)$ & \\
$\varepsilon 2 / \varepsilon 4$ & $5(6.1 \%)$ & & $2(2.9 \%)$ & $3(6.7 \%)$ & \\
$\varepsilon 3 / \varepsilon 4$ & $10(12.2 \%)$ & & $13(19.12 \%)$ & $19(42.1 \%)$ & \\
$\varepsilon 4 / \varepsilon 4$ & - & $2(2.9 \%)$ & & $1(2.2 \%)$ & \\
\hline Allele & & 0.256 & & $\mathbf{0 . 0 3 1}$ & & $\mathbf{0 . 0 0 0}$ \\
$\varepsilon 2$ & $34(20.78 \%)$ & & $33(24.2 \%)$ & & $24(26.7 \%)$ & \\
$\varepsilon 3$ & $115(70.1 \%)$ & & $84(61.8 \%)$ & & $42(46.6 \%)$ & \\
$\varepsilon 4$ & $15(9.2 \%)$ & & $19(14.0 \%)$ & & $24(26.7 \%)$ & \\
\hline
\end{tabular}


Among total subjects examined, ApoE $\varepsilon 4 / \varepsilon 4$ genotype was not found in Surabaya population. However, despite being low frequency, it was found as low as $2.9 \%$ and $2.2 \%$ in Palu and Alor population respectively. The highest $A p o E \varepsilon 2 / \varepsilon 2$ and ApoE $\varepsilon 3 / \varepsilon 4$ genotypes frequency and the lowest $A p o E \varepsilon 2 / \varepsilon 3$ and $A p o E \varepsilon 3 / \varepsilon 3$ genotypes frequency were observed in Alor population. There were no significant difference $(p>0.05)$ in $A p o E \varepsilon 2 / \varepsilon 2$ and $A p o E \varepsilon 2 / \varepsilon 3$ and $A p o E$ \&2/ $\varepsilon 4$ genotypes frequency between all of the populations. Significant difference $(\mathrm{p}<0.05)$ could be found in the frequency of $A p o E$ $\varepsilon 3 / \varepsilon 3$ in all of the populations. Similarly, no significant difference of $A p o E \varepsilon 3 / \varepsilon 4$ frequency was observed in Surabaya and Palu populations. However, the distribution of $A p o E \varepsilon 3 / \varepsilon 4$ genotype frequency showed significant difference $(p<0.05)$ between

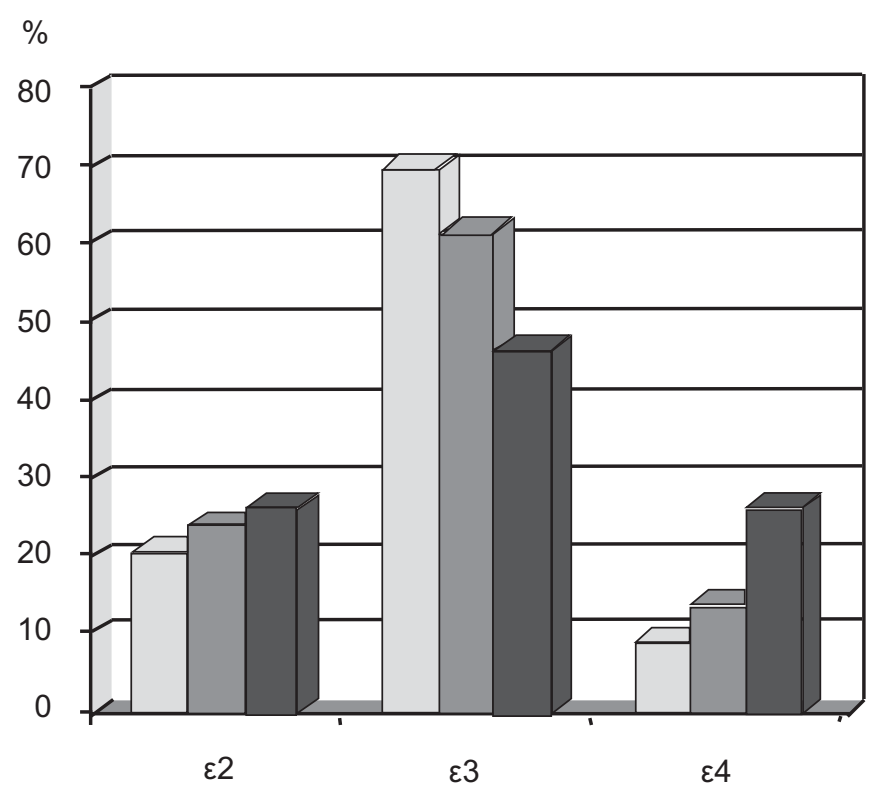

Figure 2. Distribution of ApoE alleles in Surabaya, Palu and Alor representing the western, middle and eastern populations of Indonesia ( $\square$ Surabaya $\square$ Palu $\square$ Alor )

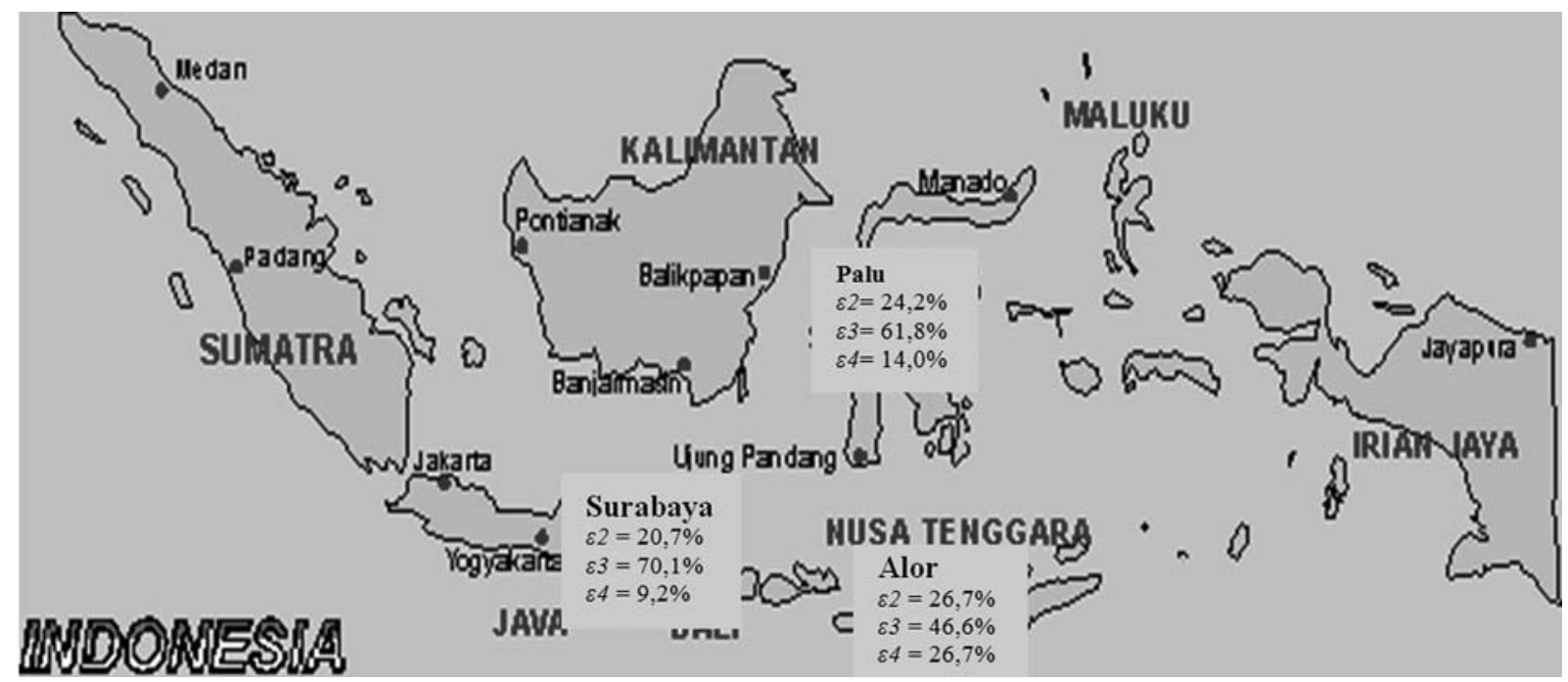

Figure 3. Frequency of apoE allele in the western, middle and the eastern of Indonesia 
Surabaya and Palu populations as well as between Palu and Alor population.

Having considered that the population of Surabaya, Palu and Alor represented the western, middle and eastern populations in Indonesia (figure 3), the frequency of $A p o E$ $\varepsilon 2, \varepsilon 3$ and $\varepsilon 4$ alleles were not significantly different between the western and middle populations of Indonesia. Similarly, the frequency of $A p o E \varepsilon 2$ allele for all three populations were not significantly different ( $\mathrm{p}>0.05)$. It is interesting that the frequency of $A p o E \varepsilon 2$ and $\varepsilon 4$ allele increased from the western to the eastern population, whereas the frequency of $A p o E \varepsilon 3$ allele was high in the western and declined to the eastern population of Indonesia. Significant difference in $A p o E \varepsilon 3$ and $A p o E \varepsilon 4$ alleles were found between the western and eastern populations of Indonesia as well as between the middle and the eastern populations of Indonesia $(\mathrm{P}<0,05)$. In contrast there was no significant difference for ApoE $\varepsilon 2$ allele frequency between the western and the middle populations of Indonesia.

\section{Discussion}

The frequency of $A p o E \varepsilon 2, \varepsilon 3, \varepsilon 4$ alleles in this study were $0.207-0.267,0.466-0.701$ and $0.092-0.267$ respectively. It can be observed from previous reports that the frequency of ApoE allele varied from population to population all of the world (Al-Bustan et al., 2005; Belkovets et al., 2001, Mastana et al., 1998; Rodrigues et al, 2005; Siest et al., 1995, Thelma et al., 2001). This present result finds high frequency of $A p o E \varepsilon 2$ allele in all three Indonesian populations studied compared to its frequency found in other Asians (Belkovets et al., 2001). Variation of ApoE $\varepsilon 4$ allele frequency ranges from $5 \%$ in Taiwan \& Sardinia to $40 \%$ in the Pygmies, while variation of ApoE $\varepsilon 3$ allele frequency ranges from $49 \%$ in Papua New Guinea to $90 \%$ in Sardinia (Siest et al., 1995). In this study, the frequency of ApoE $\varepsilon 4$ allele in the eastern population of Indonesia was the highest compared to the other two populations. It may be due to their relative isolation leading to endogamous mating which results in the increase frequency of rare variant. Compared with the ApoE \&4 frequency in Papua New Guinea population (49\%) it was shown that its frequency in the eastern population of Indonesia was lower. However, it was still the highest compared with the other two populations. In other word, the frequency of ApoE \&4 allele is lower even absent in the rest of populations of Indonesia.

It has been acknowledged that populations of the western part of Indonesia were strongly influenced by Mongoloid gene pool, while those in the eastern part of Indonesia were strongly influenced by Melanesian gene pool (Sofro, 1982). If this the case, higher frequency of $A p o E \varepsilon 4$ allele is peculiar for Melanesian populations. The influence of these two gene pools in Indonesian populations has been also confirmed by the distribution of various genetic markers and genetic relationship analysis (Sofro, 1982).

Distribution of $A p o E \varepsilon 3 / \varepsilon 3$ genotype and the frequency of $A p o E \varepsilon 3$ allele in Mongolian population were reported to be higher and significantly different with Western population and Han nations in China. In addition, ApoE $\varepsilon 4$ allele was somewhat high in Oceania $(0.221 \pm 0.149)$ than in Africa (0.209 \pm 0.090$)$, while populations in India and other Asians showed higher ApoE $\varepsilon 3$ allele frequency than in European (Gerdes et al., 1996).

In European, the frequency of $A p o E \varepsilon 4$ allele increase from the South to the North along with gradien frequency of cardiovascular disease. The ApoE $\varepsilon 4$ allele also involves not only in response to diet but also to other genetic factors (Couderc \& Bailleul, 1998). North European (Finland, Germany) tends to have high frequency of ApoE $\varepsilon 4$ (14-19\%) than south European (France, Italy) (7-12\%). Nigeria, Japan dan Finland papulations have relative low frequency of ApoE \&2 (3-4\%). MexicanAmerican and American-Indian also have low $A p o E \varepsilon 2$ allele frequency (2-4\%). In the tribes from South American-Indian, $A p o E \varepsilon 2$ allele 
was not commonly found (Eichner et al., 2002). ApoE $\varepsilon 2$ allele frequency in this study was 0.207 - 0.267. The study by Gajra et al.(1994) found $\varepsilon 2$ allele frequency in Javanese population was 0.06 . ApoE $\varepsilon 2$ allele found high in South of Africa (0.19) (Masemola et al., 2007) also in Xinjiang Uygur and Han population in China (0.193) (Yang et al.,2004). The summary of the distribution of various ApoE allele frequency among major human population as depicted in Table 2 provides worldwide polymorphism of this gene locus.

A comprehensive population genetic study three decades ago revealed that a clinal pattern was observed in the distribution of genetic markers such as Glyoxylase (GLO), Glutamate-piruvic transaminase (GPT), Phosphogluconate dehydrogenase (PGD), and Haptoglobin ( $\mathrm{Hp}$ ) across the Indonesian archipelago. There was a trend toward increasing GPT ${ }^{1}, \mathrm{PGD}^{\mathrm{C}}$ and and $\mathrm{Hp}^{1}$ frequencies and decreasing $\mathrm{GLO}^{1}$ gene frequency towards the east. For systems with more specific alleles such as Phosphoglucomutase (PGM) and Transferrin (Tf), the distribution of $\mathrm{PGM}^{2}$ and $\mathrm{Tf}^{\mathrm{D} 1}$ showed a western limit as far as Java and the distribution of $\mathrm{TfD}^{\mathrm{Chi}}$ and $\mathrm{HbE}$ showed an eastern limit as far as Halmahera in the north and Timor in the south (Sofro, 1982). In a more recent study, Indonesian populations can be genetically grouped into three clusters i.e. cluster I consisted of the populations with strong influence from the Mongoloid gene pool, whose mostly living in the western part of the country, cluster II consisted of populations who shared both Mongoloid and the Austro-Melanesian gene pool, whose living in the middle part of the country and cluster III signified by Austro-Melanesian gene pool mostly living in the eastern part of the Indonesian archipelago (Lanni 2002). ApoE gene polymorphism from these three respective populations also provide more or less similar pattern. No difference was observed in the distribution of $A p o E \varepsilon 2$ allele in all populations. The frequency of $A p o E \varepsilon 2, \varepsilon 3$, and $\varepsilon 4$ alleles were not different either between the western and the middle population, but the frequency of $A p o E \varepsilon 3$ and $\varepsilon 4$ alleles was different in the eastern populations compared to the western and middle populations.

The present study confirms genetic variability of ApoE genotypes and alleles across world populations. The subjects examined were all healthy individuals however, the impact of this genetic variability is important in relation to diseases. Speculation may be made and is important to clarify the association of ApoE gene with cardiovascular and other disorders in various populations (Abboud et al., 2008; Jasinska-Myga et al., 2007)

Studies investigating the relationship of ApoE polymorphism to vascular disease risk in different ethnic groups are also important and may providenew insights into underlying mechanisms contributing to the etiology of vascular disease (Erdembileg \& Lars, 2008). This result support that the western and middle

Table 2. Distribution of various APOE alleles (frequency range) among major human populations

\begin{tabular}{lllll}
\hline $\begin{array}{l}\text { Population } \\
\text { Group }\end{array}$ & $\varepsilon 2$ & $\varepsilon 3$ & $\varepsilon 4$ & Source \\
\hline Europeans & $0.044-0.119$ & $0.64-0.898$ & $0.052-0.310$ & Belkovelts et al.2001 \\
Africans & $0.031-0.116$ & $0.536-0.850$ & $0.085-0.407$ & \\
Asians & $0.02-0.140$ & $0.620-0.870$ & $0.070-0.240$ & \\
Native Americans & $0.0-0.014$ & $0.720-0.911$ & $0.089-0.280$ & Masemola et al., 2007 \\
Oceanians & $0.0-0.110$ & $0.486-0.740$ & $0.260-0.360$ & \\
South of Africa & 0.190 & 0.518 & 0.293 & \\
& & & & \\
This research & & & 0.092 & \\
Surabaya & 0.207 & 0.701 & 0.14 & \\
Palu & 0.242 & 0.618 & 0.267 & \\
Alor & 0.267 & 0.466 & & \\
\hline
\end{tabular}


population of Indonesian has different gene pool with their eastern counterpart, so the characteristics of disease or management of patients might be somewhat different. This study can be extended to other populations in Indonesia with unique gene pool suffering from any disorders possibly influenced by ApoE genotype.

It is concluded that genetic variation of ApoE gene was found in three populations i.e. Surabaya, Palu and Alor, each representing populations with strong influence of Mongoloid gene pool, populations sharing Mongoloid and Austro-Melanesian gene pool and populations with strong influence of Austro-Melanesian gene pool respectively. Three alleles and five genotypes were distributed in all populations studied with the exception of $A p o E \varepsilon 4 / \varepsilon 4$ which was not found in Surabaya. The frequency of three ApoE alleles in the western and middle populations of Indonesia was not significantly different however, significant difference was observed in the frequency of ApoE $\varepsilon 3$ and $\varepsilon 4$ alleles from the eastern compared to those in the western and middle populations of Indonesia.

\section{Acknowledgements}

The authors appreciate Dr. Fransisca Lanni as a member of Biochemical Genetic Group from the Research Center for Biotechnology UGM and Department of Biochemistry Faculty of Medicine UGM for collecting samples from various Indonesian populations and fruitful discussion. The authors are very much indebted to Research Center for Biotechnology UGM for providing laboratory space to carry out this work.

\section{References}

Abboud S, Viiri LE, Lutjohann D, Goebelet S, Luoto T, Friedrichs S, Desfontaines P, Gazagnes M, Laloux P, Peeters A, Seeldrayers P, Lehtimaki T, Karhunen P, Pandolfo M, Laaksonen R. 2008. Associations of apolipoprotein $\mathrm{E}$ gene with ischemic stroke and intracranial atherosclerosis. Eur. J. Hum. Genet., 16, 955-960.

Al-Bustan SA, Alnaqeeb MA, Annice BG, Ibrhim G, Al-Rubaian J, Ahmed AH, Refai TM., 2005, Apolipoprotein E genotyping among the healthy Kuwaiti population. Hum. Biol., 77(4), 487-498.

Belkovets A, Kurilovich S., Dolgich M, Agarwal DP., 2001, Distribution of apolipoprotein $\mathrm{E}(\mathrm{ApoE})$ genotypes in Siberian Female Population sample, IJHG, 1(3), 179-182

Corella D, Guill M, Carmen S, Portol A, Sabater A, Cortina S, Folch J, Gonz JI, Ordovas JM, 2002, Environmental factors modulate the effect of the APOE genetic polymorphism on plasma lipid concentrations: Ecogenetic studies in a Mediterranean Spanish population, J. Biochem. Soc., 132 (50), 743-749

Couderc R, BailleulS,1998Des, Apolipoprotein $E$ and its alleles in healthy subjects and in atherosclerosis, Ann. Biol. Clin., 56(6), 651-659

Dawson B, Gillow J, 1994, The traditional Architecture of Indonesia, London:Thames and Hudson Ltd p 7 ISBN 0-500-34132-X

Douglas CE, 2002, Mortality differences by APOE genotype estimated from demographic synthesis, Gen. Epid., 22 ,146-155

Eichner JE, Terence Dunn S, Perveen G, Thompson DM, 2002, Apolipoprotein E Polymorphism and Cardiovascular Disease : A HuGE Review, Am. J. Epid., 155(6), 487-495

Elosua R, Ordovas JM, Cupples LA, Fox CS, Polak JF, Wolf PA, D'Agostino, SR. RA and O'Donnell CJ, 2004, Association of ApoE genotype with carotid atherosclerosis in men and women : The Framingham Heart Study, J. Lipid Res., 45, 1868-1875

Erdembileg A, Lars B, 2008, Apolipoprotein $\mathrm{E}$ and cardiovascular diseases, Indian J. Med. Sci., 62(3), 85-86

Gajra B., Candlish JK., Saha N., Heng CK., Soemantri AG., Tay JS., 1994, Influence 
of polymorphisms for apolipoprotein B (Ins/del, Xbal, EcoR) and apolipoprotein E on serum lipids and apolipoproteins in Javanese population, Genet. Epidemiol., 11(1), 19-27

Gerdes LU, Gerdes C, Hansen PS, Klausen IC, Faergeman O, Dyerberg J, 1996, The apolipoprotein polymorphism in Greenland Inuit in its global perspective, Hum. Genet., 98(5), 546-550

Jasinska-Myga B, Opala G, Goetz CG, Tustanowski J, Ochudio S, Gorzkowska A, Tyrpa Jadwiga. 2007. Apolipoprotein E Gene Polymorphism, Total Plasma Cholesterol Level, and Parkinson Disease Dementia. Arch. Neurol., 64, 261-265.

Jurkovicova D, Goncalvesova E, Sedlakova B, Hudecova S, Fabian J and Krizanova O, 2006, Is the ApoE Polymorphism Associated with dilated cardiomyopathy? Gene. Physiol. Biophys., 25, 3 -10

Lanni F, 2002, Heterogenitas molekular gena globin- $\beta$ di Indonesia : Kaitannya dengan pola penyebaran Thalassemia$\beta$ serta hubungan genetik antar populasi di Indonesia, Disertasi Doktor, Universitas Gadjah Mada

Mahley R.W, Ji Z-S, 1999, Remnant Lipoprotein Metabolism : Key pathways involving cell-surface heparan sulfate proteoglycans and apolipoprotein E, J. Lipid Res., 40, 1-16

Masemola ML, Alberts M, Urdal P., 2007 Aug, Apolipoprotein E genotypes and their relation to lipid levels in a rural South African population. Scand. J. Public Health_Suppl., 69, 60-65.

Mastana SS, Calderon R, Pena PH, PapihaSS, 1998, Anthropology of apolipoprotein E (ApoE) gene) : low frequency of ApoE4 allele in Basques and in tribal (Baiga) population of India, Ann. Hum. Biol., 25(2), 137-143

Merdekawaty E, 2006, "Bahasa Indonesia” and languages of Indonesia" (PDF). (UNIBZ)introduction to Linguistics. Free university of Bozen. http:/ / www.languagesstudies. unibz.it; "An overview of Indonesia",
Living in Indonesia, A site for expatriates. Expat Web site Association, http:/ / www. expat.or.id/info/overview.html. Retrieved 2006-10-05

Minihane AM, Jofre-Monseny L, Olano-Martin E, Rimbach G, 2007, Apolipoprotein E Genotype, cardiovascular risk and responsiveness to dietary fatmanipulation, Proc. Nutr. Soc., 66(2), 183-97

Rodrigues MO, Fonseca A, Dias CM, Albergaria I, Martins G, Alpendre ML, Do Carmo Martins M, 2005, ApoE genotypes and dyslipidemias in samples of Portugese population, Clin. Chem. Lab. Med., 43(9), 907-912

Siest G, Pillot T, Regis BA, Muller BL, Steinmetz J, Galteau MM, Visvikis S, 1995, Apolipoprotein E : an important gene and protein to follow in laboratory medicine, Clin. Chem., 41(8), 1068-1086

Singh P, Singh M, Mastana SS. 2006, APOE distribution in world populations with new data from India and the UK. Ann. Hum. Biol., 33(3), 279-308

Sofro ASM, 1982, Population Genetic Studies in Indonesia, PhD Dissertation, The John Curtis School of Medical Research, Australian National University

Thelma BK, Ramesh CJ, Hiroko HD, Rajesh $\mathrm{P}, 2001$, ApoE polymorphisms in a rural older population-based sample in India, Hum. Biol., 73, 135-144

Yang SL, He BX, Liu HL, He ZY, Zhang H, Luo JP, Hong XF, Zou YC,. 2004, Apolipoprotein E gene polymorphisms and risk for coronary artery disease in Chinese Xinjiang Uygur and Han population, Chin. Med. Sci. J., 19(2), 150154

Zivelin A, Rosenberg N, Peretz H, Amit Y, Kornbrot N, Selogsohn U, 1997, Improved method for genotyping apolipoprotgein E polymorphisms by a PCR-based assay Simultaneously Utilizing Two Distinct Restriction enzymes, Clin. Chem., 43(9), 1657-1659 